\title{
Parentage Confirmation of Korean Bred Pear Cultivars by Simple Sequence Repeat SSR Genotyping and $S$-Genotypes Analysis
}

\author{
Hoy-Taek Kim, Arif Hasan Khan Robin, Ill-Sup Nou* \\ Department of Horticulture, Sunchon National University, Suncheon 57922, Korea
}

\begin{abstract}
Identification and authentication of parentage are important for effective pear breeding. Within Korean pear cultivars discrepancies are often reported between parents and offspring in skin color of fruits and also in $S$-genotypes suggesting that reported parentage was often inappropriate. In Korea, the parentage of the most of pear cultivars was never confirmed at the molecular level. Simple sequence repeat (SSR) genotyping and $S$-genotype analysis are considered effective in identifying parents. In this study, parentage of nine Korean bred cultivars was confirmed using SSR genotyping and $S$-genotype analysis. A total of 53 SSR markers were used. Six different haplotype-specific endonucleases were used for restriction cleavage of $S$-genotypes. Most of the Korean bred cultivars had six comparatively shorter $S$-RNase, $S^{1}, S^{3}, S^{4}, S^{5}, S^{6}$, or $S^{7}$ of 450 bp in length whereas the Japanese control cultivars had four other comparatively longer $S$-RNase. Out of nine pear cultivars only 'Chuwhangbae' and 'Whangkeumbae' had identical SSR genotypes and $S$-genotype with previously reported parents. For another cultivar, 'Sujeonbae', the parents were the mutants of reported parent, 'Niitaka'. For four other cultivars, SSR and $S$-genotypes of offspring matched with only one reported parent 'Niitaka' but those of another parent did not match. For the two other pear cultivars 'Soowhangbae' and 'Sooyoung' none of reported parents were confirmed by SSR genotyping and S-genotype analysis. Historically, the parent 'Niitaka' was predominant in the Korean pear breeding programs because of its high yield potential and quality. The methods have been used in this study could be used to identify pear cultivars with diverse $S$-genotypes to eliminate any existing obscure parent-offspring relations.
\end{abstract}

Keywords Pears, SSR genotype, $S$-genotype, $S$-RNase

\section{INTRODUCTION}

Pear (Pyrus spp.) is one of the important fruit in the world that is cultivated in more than 50 countries. In Korea, some local pear cultivars such as, 'Whangsilri', 'Cheongsilri' (Pyrus ussuriensis var. ovoidea Rehder), 'Cheongdangrori', 'Habsilri' ( $P$. ussuriensis var. viridis T.B. Lee) were being cultivated until the beginning of 19 th century. Breeding of Korean pear cultivars ( $P$. pyrifolia Nakai) was started in the late 1920s at the National Institute of Horticultural and Herbal Science (NIHHS) of Rural Development Administration (RDA) in South Korea. The breeding goals at that time were increasing fruit size and improving fruit quality that includes desirable $\mathrm{pH}$, sugar content, flesh firmness and core ratio and also development of disease and pest resistance such as, black spot, scab and mite resistance
(Shin et al. 2002). Besides those, utilization of self-compatibility phenomenon was an additional breeding objective aimed to develop labor-saving varieties (Shin et al. 2002). As a part of that extensive pear breeding efforts throughout the 19 th century a total of 27 pear cultivars were released by NIHHS between 1969 and 2009 (Cho et al. 2012). A notable number of varieties including 'Chuwhangbae', 'Whangkeumbae', 'Hanareum', 'Shincheon', 'Soowhangbae', 'Josengwhangkeum', 'Sunhwang' and 'Sooyoung' were bred by using 'Niitaka' as one of the parent in those breeding programs. But the same parent 'Niitaka' was not used for some other cultivars such as 'Chuwhangbae' and 'Soowhangbae' (Kim et al. 1986; Hwang et al. 2002; 2005a; 2005b; Shin et al. 2007). Simple sequence repeat (SSR) genotyping in a few notable studies also confirmed that 'Niitaka' was not the parent of some pear cultivars as

Received May 13, 2016; Revised May 18, 2016; Accepted May 19, 2016; Published May 31, 2016

*Corresponding author Ill-Sup Nou, nis@sunchon.ac.kr, Tel: +82-61-750-3249, Fax: +82-61-750-5389 
previously reported (Sawamura et al. 2008; Kim and Nou 2016). Other than variation in SSR genotyping of some pear cultivars, such as, 'Housui' (Machida et al. 1982; Ishimizu et al. 1998), 'Kisui' (Hiratsuka et al. 1998), 'Tanzawa' (Castillo et al. 2001), 'Niitaka' (Takasaki et al. 2004) and 'Oharabeni' (Kim et al. 2007) some of them had discrepancies from their reported parents in terms of skin type and $S$-genotypes. The registrant parents 'Ri-14' $\left(S^{1} S^{2}\right)$ and 'Yakumo' $\left(S^{1} S^{4}\right.$ and/or $\left.S^{2} S^{4}\right)$ of 'Housui' had smooth skin and a different genetic makeup for self-incompatibility compared to their offspring 'Housui' (Machida et al. 1982; Ishimizu et al. 1998). Kimura et al. (2003) analyzed the parentage of 14 pear cultivars by using 20 SSR markers and confirmed that 'Ri-14' and 'Yakumo' were not the parents of 'Housui'. The parents of 'Housui' were 'Kousui' (female parent) and 'Hiratsuka 1 gou' (synonym 'I-33', male parent) as reported by Sawamura et al. (2004) after SSR genotyping. Furthermore, in a separate study parentage of 55 Japanese pear cultivars was identified by using $S$-RNase allele and 18 SSR markers (Sawamura et al. 2008). The study by Sawamura et al. (2008) thus identified discrepancy of SSR-genotypes between 10 hybrid cultivars ('Kisui', 'Tanzawa', 'Niitaka', 'Seiryu', 'Akemizu', 'Atago', 'Echigonishiki', 'Ishiiwase', 'Shusui', and 'Yachiyo') and their previously reported parents and suggested that these hybrid cultivars have new candidate parents. However, identifying the parent-offspring relationships of pear cultivars is very important to improve breeding efficiencies.

Polymorphism exists in $S$-genotypes at the $S$-RNase locus that controls self-incompatibility was previously utilized for the identification of Japanese and Korean bred pear cultivars (Ishimizu et al. 1999; Kim et al. 2002; 2007). In addition, DNA marker based profiling techniques could be also utilized for identifying the parents of pear cultivars. Teng et al. (2002) used random amplified polymorphic DNA markers to classify 118 Asian pear cultivars. Monte-Corvo et al. (2001) reported that inter-simple sequence repeat was effective for identifying parents of $P$. communis L. cultivars of European origin. Kim et al. (2012) analyzed 80 pear cultivars among them 64 were Japanese ( $P$. pyrifolia), 10 were Chinese ( $P$. ussuriensis) and six were European in origin based on their BRIP markers associated DNA profiling. The authors were able to differentiate cultivar 'Housui' from the other Japanese pear cultivars. A large number of SSR markers have been developed in the last two decades from genomic DNAs and ESTs in Japanese and European pears (Yamamoto et al. 2002; 2004; Fernandez-Fernandez et al. 2006; Nishitani et al. 2009). The use of these SSR markers has allowed DNA profiling, parentage analysis, and evaluation of genetic diversity in pear cultivars. To discern the real parent-offspring relationship, some apple cultivars were investigated with $S$-RNase analysis and SSR markers and revealed their true parentage (Kitahara et al. 2005; Moriya et al. 2011)

In Korea, Cho et al. (2012) used 19 sequence-characterized amplified region (SCAR) markers and nine SCAR markers to distinguish 39 pear cultivars (25 Korean pear cultivars and 14 Japanese pear cultivars). Recently, the SNPS, InDels, and SSRs detected between two cultivars 'Whangkeumbae' and 'Minibae' by using NGS data have been mapped to the reference genome of the Chinese pear 'Suli' (P. bretschneideri) (Oh et al. 2015). The number of total SSRs for 'Whangkeumbae' and 'Minibae' was 75,000 among them 1,200 were found polymorphic. Despite availability of sufficient techniques and markers, to date the parent-offspring relationship of Korean bred pear has not been analyzed. In this study, the nine Korean bred pear cultivars were analyzed using the $S$-genotypes with $S$-RNase analysis and SSR genotypes with 53 SSR markers to confirm their parent-offspring relationship.

\section{MATERIALS AND METHODS}

\section{Plant materials, candidate parent selection and isolation of DNA}

The nine Korean bred pear cultivars were collected at the NIHHS (Cho et al. 2012; Table 1). SSR genotyping data of 98 pear cultivars were obtained from the literature (Yamamoto et al. 2002; 2004; 2006; 2007; Kimura et al. 2003; Sawamura et al. 2004; Sawamura et al. 2008; submitted manuscript). Candidate parents were selected using MARCO software with 53 SSR markers information. All candidate parents were of Japanese origin. Twelve candidate parent-pear cultivars were collected at the National Institute of Fruit Tree Science (Ibaraki, Japan) 
Table 1. The 9 Korean bred pear cultivars and 12 Japanese candidate pear parent cultivars used in this experiment.

\begin{tabular}{lll}
\hline \hline Cultivar (synonym) & \multicolumn{1}{c}{ Registrant parents } & Origin \\
\hline Chuwhangbae & Imamuraaki $\left(S^{1} S^{6}\right) \times$ Nijisseiki $\left(S^{2} S^{4}\right)$ & Korea \\
Whangkeumbae & Niitaka $\left(S^{3} S^{9}\right) \times$ Nijisseiki $\left(S^{2} S^{4}\right)$ & Korea \\
Hanareum & Niitaka $\left(S^{3} S^{9}\right) \times$ Chuwhangbae $\left(S^{3} S^{4}\right)$ & Korea \\
Shincheon & Niitaka $\left(S^{3} S^{9}\right) \times$ Chuwhangbae $\left(S^{3} S^{4}\right)$ & Korea \\
Soohwangbae & Chojuro $\left(S^{2} S^{3}\right) \times$ Kimitsukawase $\left(S^{1} S^{5}\right)$ & Korea \\
Josaenghwangkeum & Niitaka $\left(S^{3} S^{9}\right) \times$ Shinko $\left(S^{4} S^{9}\right)$ & Korea \\
Sunhwang & Niitaka $\left(S^{3} S^{9}\right) \times$ Okusankichi $\left(S^{5} S^{7}\right)$ & Korea \\
Sooyoung & Niitaka $\left(S^{3} S^{9}\right) \times$ Soohwangbae $\left(S^{3} S^{4}\right)$ & Korea \\
Sujeongbae & Mutant of Niitaka $\left(S^{3} S^{9}\right)$ & Korea \\
Imamuraaki & Breeding process is unknown & Japan \\
Nijisseiki & Discovered in 1888 , named in 1904 & Japan \\
Niitaka & Amanogawa $\left(S^{1} S^{9}\right) \times$ Chojuro $\left(S^{2} S^{3}\right)$ & Japan \\
Chojuro & Sown in 1889 , fruited in 1893 & Japan \\
Kimitsukawase & Shinkozo $\times$ Doitsu $\left(S^{1} S^{2}\right)$ & Japan \\
Okusankichi & Sown in $1840-1850$ & Japan \\
Tama & Gion $\left(S^{2} S^{4}\right) \times$ Kosui $\left(S^{4} S^{5}\right)$ & Japan \\
Chouju & Asahi $\left(S^{4} S^{5}\right) \times$ Kimitsukawase $\left(S^{1} S^{5}\right)$ & Japan \\
Shinsui & Kikusui $\left(S^{4} S^{4}\right) \times$ Kimitsukawase $\left(S^{1} S^{5}\right)$ & Japan \\
Shinko & Nijisseiki $\left(S^{2} S^{4}\right) \times$ Amanokawa $\left(S^{1} S^{9}\right)$ & Japan \\
Ichiharawase & Discovered in 1892 or 1893 & Japan \\
Kinchaku & Breeding process is unknown, local cultivar & Japan \\
\hline
\end{tabular}

(Sawamura et al. 2008; Table 1). Genomic DNA was extracted from young leaves by using a Genomic tip 20/G (Qiagen, Germany) using the method previously followed by Yamamoto et al. (2006). The extracted genomic DNA was used for SSR analysis and polymerase chain reaction (PCR)-cleaved amplified polymorphic sequences analysis of $S$-RNases.

\section{Data analysis and SSR genotyping by SSR markers}

A total of 53 SSR markers were selected from 96 SSR markers developed for apple and pear (Yamamoto et al. 2002; 2004; 2006; 2007). PCR amplification was performed according Yamamoto et al. (2002) except that the forward primers labeled with a fluorescent dye. The PCR products were separated by electrophoresis on a POP-4 polymer and detected using a Genetic Analyzer 3100 (PE Applied Biosystems, DriveFoster City, CA, USA). The size of amplified bands was scored using an internal DNA standard (GeneScan-400HD ROX; PE Applied Biosystems) with GeneScan software (PE Applied Biosystems). The parent-offspring relationships of Korean bred pear cultivars were analyzed by comparing the SSR alleles in each cultivars with registrant parents using the MARCO software (Fujii et al. unpublished as cited by Shoda et al. 2012). Furthermore, to identify minimal number of marker subsets, MinimalMarker software (Fujii et al. 2007) was used because that was necessary to distinguish all of the cultivars to find out identical genotypes of the 21 cultivars generated by the 53 SSR markers.

\section{S-RNase genotyping by PCR-restriction fragment length polymorphism (RFLP) analysis}

PCR amplification was performed using the $S$-RNasespecific primers, FTQQYQ (TTTACGCAGCAATATCAG) and PSprI (DKWCSCRCAGGWGCCATGTTT), which were designed from $S$-RNase high homology region of pear and amplified $S^{1}$ to $S^{9}$-RNase and $S^{\mathrm{k}}$-RNase, as described by Kim et al. (2007). The amplified $S$-RNase fragments were checked and digested with the haplotypespecific restriction enzymes $S f c \mathrm{I}\left(S^{1}\right), P p u \mathrm{MI}\left(S^{3}\right.$ and $\left.S^{5}\right)$, NdeI $\left(S^{4}\right), A l w \mathrm{NI}\left(S^{5}\right)$, and $B s t \mathrm{BI}\left(S^{9}\right)$ to determine their size after agarose gel electrophoresis as described by Kim et al. (2002). 


\section{RESULTS}

\section{Determination of candidate parent of Korean pear cultivars by using SSR genotyping}

SSR genotyping based on 53 SSR markers revealed the parentage of nine Korean bred pear cultivars (Table 2). The SSR genotypes of 'Chuwhangbae' ('Imamuraaki' $\times$ 'Nijiiseiiki') and 'Whangkeumbae' ('Nijiiseiki' $\times$ 'Niitaka') were confirmed and matched with the registrant parents SSR genotypes by all SSR markers (Table 2). We confirmed that one SSR allele each from 'Hannareum', 'Shincheon', 'Josaengwhangkum' and 'Sunhwang' was inherited from registrant parent 'Niitaka', i.e., those 4 pear cultivars had one identical SSR allele of 'Niitaka' (Table 2). But they did not have identical SSR alleles with another registrant parents. In addition, two cultivars 'Soowhangbae' and 'Sooyoung' had different SSR alleles that were not matched with parents (Table 2). Therefore, we concluded that two pear cultivars 'Chuwhangbae' and 'Whangkeumbae' were bred from a breeding program between registrant parent, but other six pear cultivars were bred from a cross between other non-reported parents. Also, the SSR genotype of 'Sujeongbae' being a mutant of 'Niitaka' was identical with 'Niitaka' (data not shown).

The 53 SSR alleles of five pear cultivars were inherited from SSR alleles of each parent. The candidate parents of 'Hannareum' were 'Niitaka' and 'Tama'; those of 'Shincheon' were 'Niitaka' and 'Chouju'; those of 'Sunhwang' were 'Niitaka' and 'Shinsui', and those of 'Soowhangbae' were 'Niitaka' and 'Nijisseiki' (Table 3). The cultivar 'Josaengwhangkum' was the offspring of 'Niitaka' and 'Nijisseiki' similar to 'Whangkeumbae' although 'Shinko' was the reported parent instead of 'Nijisseiki' (Table 3). Therefore we suggested that the pear cultivars developed between 1966 and 1986, 'Soowhangbae', 'Josaengwhangkum' and 'Whangkeumbae' were the selected offspring of a cross between 'Niitaka' and 'Nijisseiki'. The cultivar 'Okusankichi' was identified as one candidate parent of 'Sooyoung' (Table 3). The cultivar 'Niitaka' was another reported parent of 'Sooyoung' (Table 3). However out 53 SSR alleles not even one allele of 'Sooyoung' matched to 'Niitaka'. Thus the second parent of cultivar 'Sooyoung' remain obscure.

\section{S-genotyping by $S$-RNase PCR-RFLP analysis}

The $S$-genotypes of following five Korean pear cultivars: 'Sujeongbae', 'Hannareum', 'Shincheon', 'Sooyoung' and 'Josaengwhangkum' were identified by $S$-RNase PCRRFLP analysis in this study. The $S$-genotypes of remaining four cultivars in Table 1 were studied by Kim et al. (2002). The $S$-RNase PCR analysis amplified $S$-locus of 11 pear cultivars including six control pear cultivars of Japanese origin and five Korean cultivars. S-genotyping identified nine different types of S-locus from $S^{1}$ to $S^{9}$ and $S^{\mathrm{k}}$-RNase (Fig. 1). $S^{1}, S^{3}, S^{4}, S^{5}, S^{5}$ or $S^{7}$-RNase were about 450 bp in length, $S^{8}$-RNase was $500 \mathrm{bp}$ in length, $S^{\mathrm{k}}$-RNase was 1,065 bp length and $S^{2}$ and $S^{9}$-RNase were 1,414 bp and $1,374 \mathrm{bp}$ in length respectively. The Japanese control pear cultivars had all $S$-RNase whereas four Korean cultivars (except 'Sujeongbae') had only the shortest $S^{1}, S^{3}, S^{4}, S^{5}, S^{5}$, or $S^{7}$-RNase of 450 bp length. The cultivar 'Sujeongbae' had $S^{9}$-RNase in addition to other six types of $S$-RNase present in four other Korean cultivars (Fig. 1). For the determination of $S$-genotype, the $S$-RNase PCR fragments of 5 Korean pear cultivars were digested with $S$-allele specific enzymes (PpuMI; $S^{3}$ - and $S^{5}$-allele specific, $A l w \mathrm{NI} ; S^{5}$-allele specific, $B s t \mathrm{BI} ; S^{9}$-allele specific, $N d e \mathrm{I}$; $S^{4}$-allele specific and $S c f 1$; S1-allele specific) (Fig. 2). The $S$-RNase PCR fragments of 'Sujeongbae' were digested with $P p u \mathrm{MI}\left(S^{3}\right.$ - and $S^{5}$-allele specific) and $B s t \mathrm{BI}\left(S^{9}\right.$-allele specific), but was not digested with $A l w$ NI $\left(S^{5}\right.$-allele specific) (Fig. 2A). Thus, the $S$-genotype of 'Sujeongbae' was determined as $S^{3} S^{9}$. The $S$-genotype of 'Sujeongbae' corresponded with the $S$-genotype of 'Niitkata' $\left(S^{3} S^{9}\right)$ because the 'Sujeongbae' is a mutant of 'Niitkata' (Fig. 2). The S-RNase PCR fragments of 'Hannareum' and 'Josaengwhangkum' were digested with $S^{3}$ - and $S^{4}$-allele specific-enzymes (Fig. 2B, C). The $S$-genotypes of 'Hannareum' and 'Josaengwhangkum' were identical, $S^{3} S^{4}$ (Fig. 2). The $S$-RNase PCR fragments of 'Shincheon' were digested with $S^{1}$ - and $S^{3}$-allele specific endonucleases. The $S^{5}$-allele specific endonuclease was unable to digest the $S$-RNase PCR fragments of 'Shincheon' (Fig. 2D). Thus, the $S$-genotype of 'Shincheon' was determined as $S^{1} S^{3}$ that was not corresponded with the $S$-genotype of registrant parents 'Niitaka' $\left(S^{3} S^{9}\right)$ and 'Chuwhangbae' $\left(S^{4} S^{5}\right)$. The 


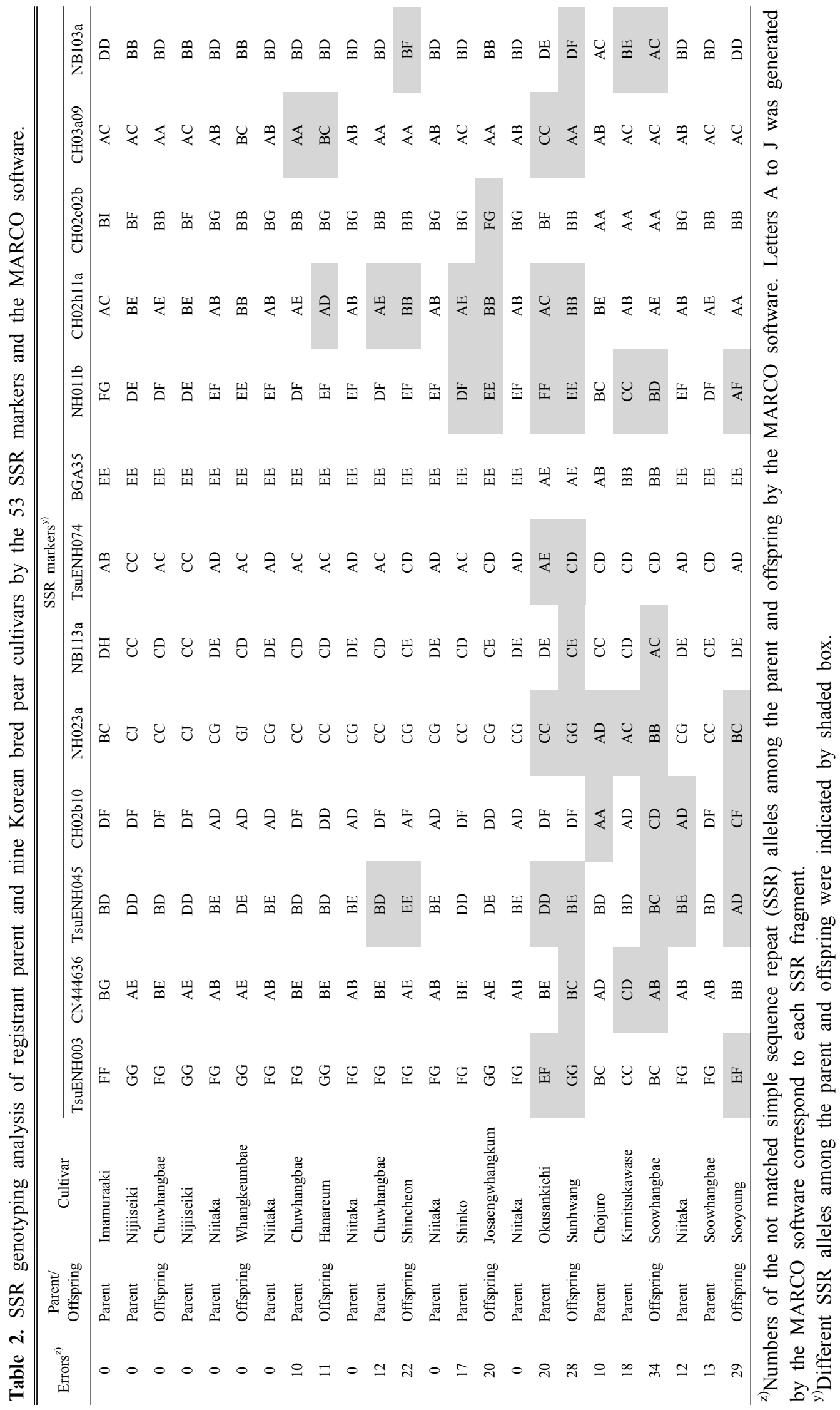




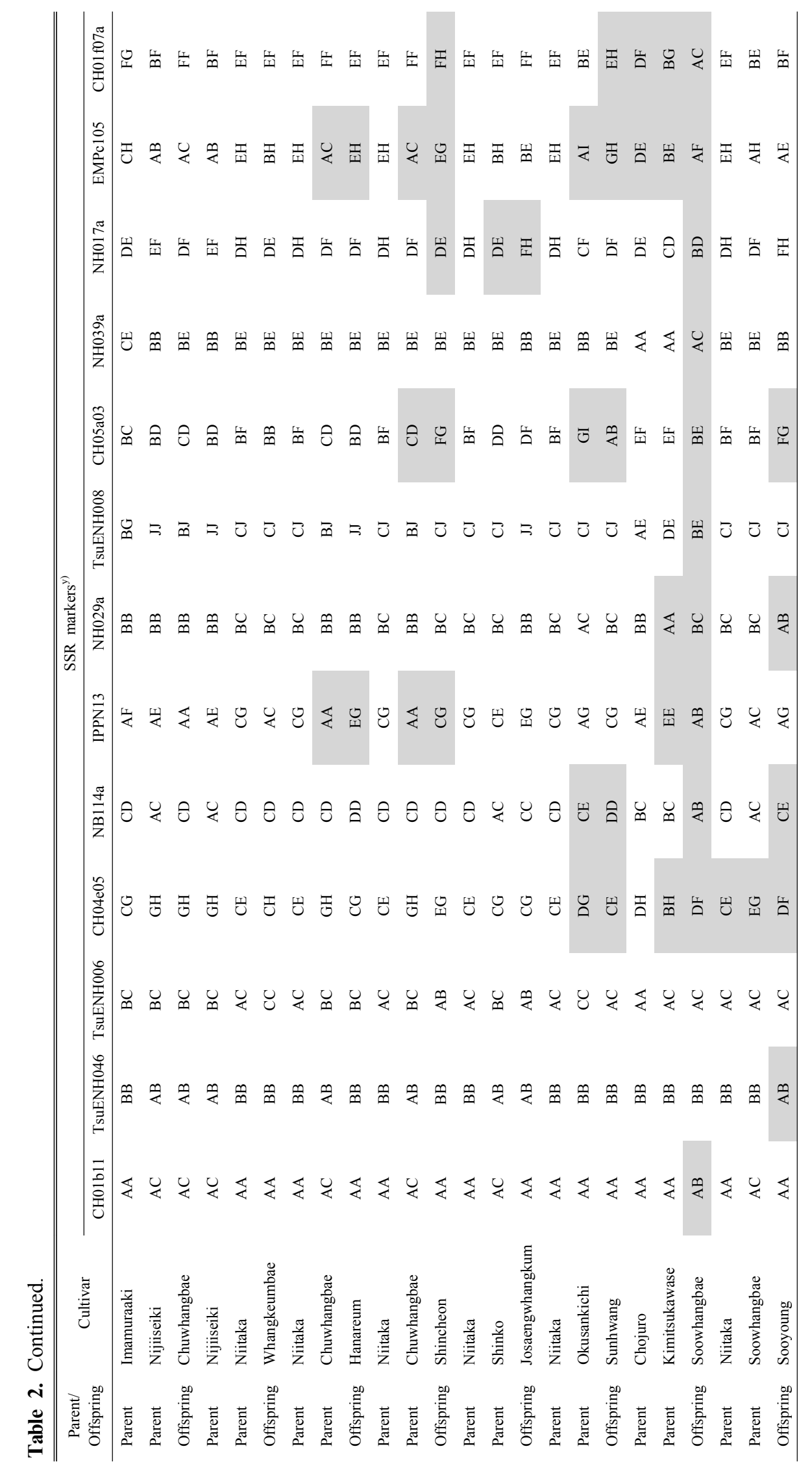




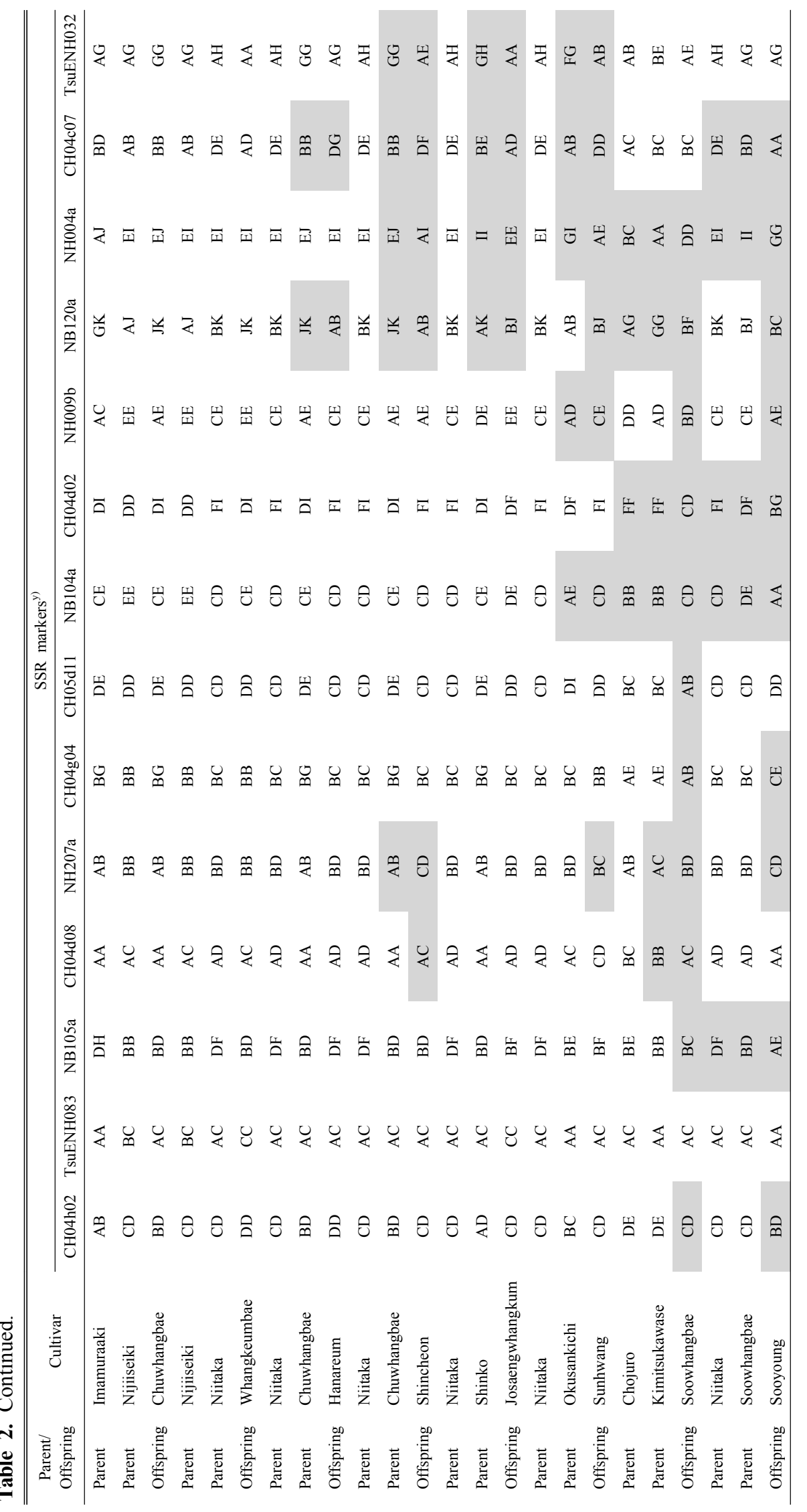




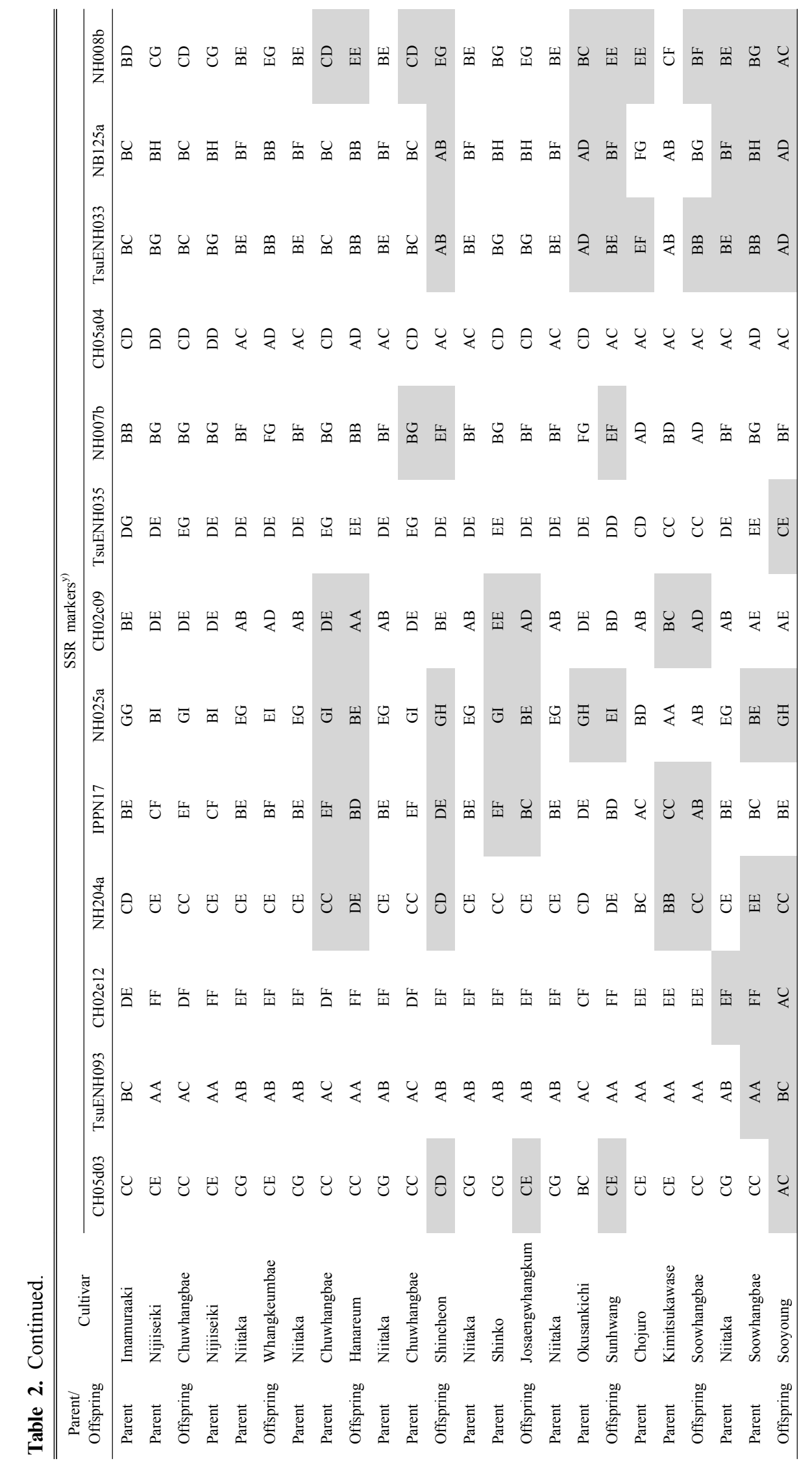




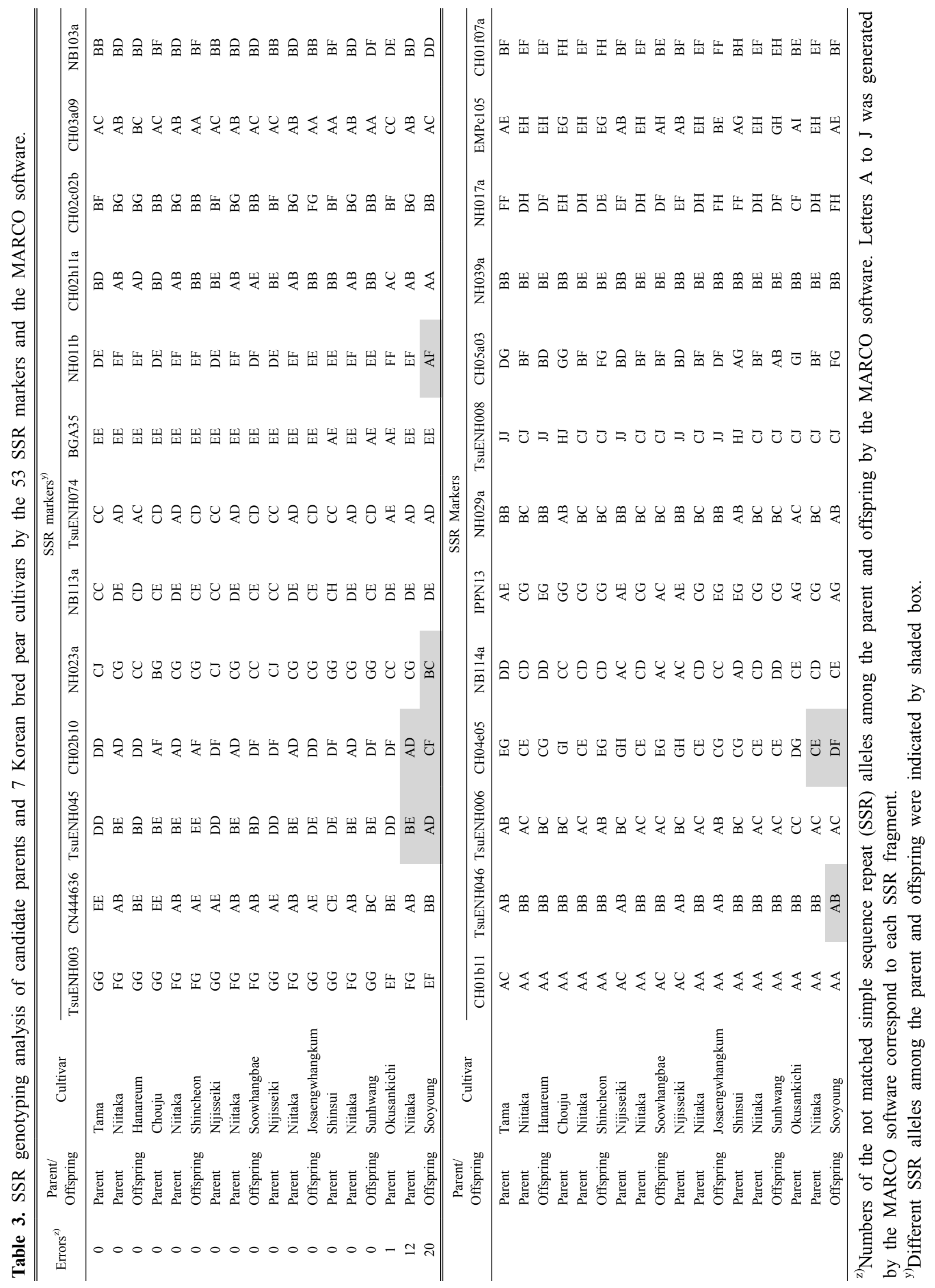




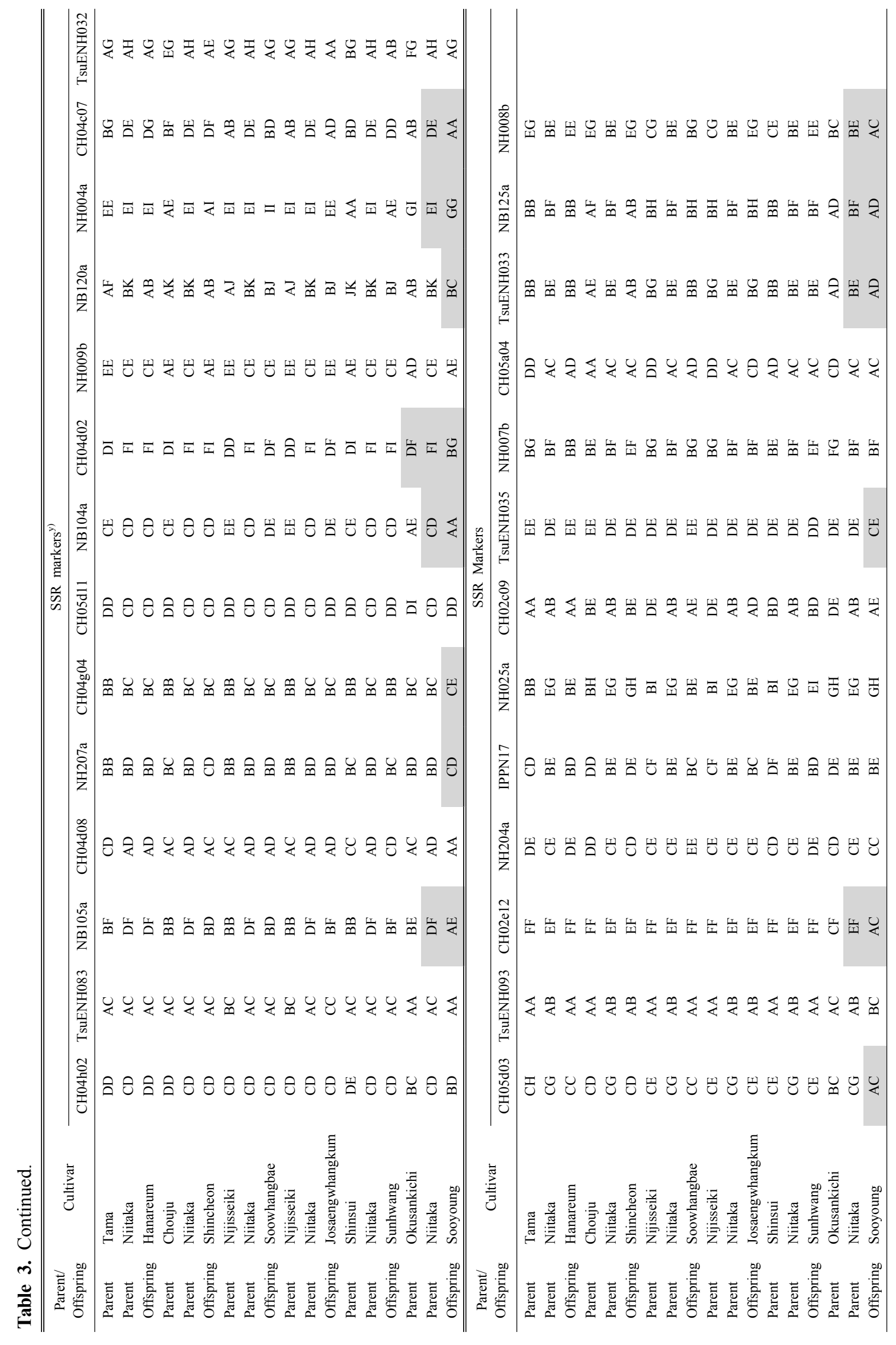




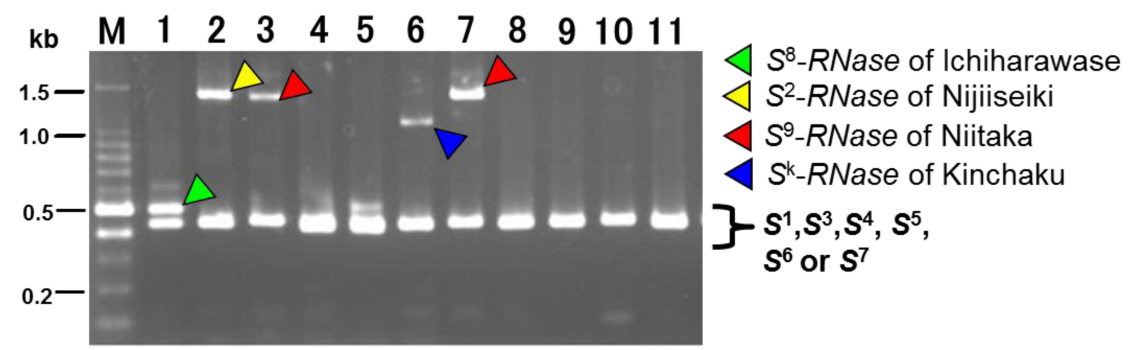

Fig. 1. $S$-RNase polymerase chain reaction analysis of 6 Japanese pear cultivars of known $S$-genotypes and 5 Korean bred pear cultivars by using the FTQQYQ-Fam and PsprI primers. Lane 1: Ichiharawase $\left(S^{1} S^{8}\right)$, lane 2: Nijisseiki $\left(S^{2} S^{4}\right)$, lane 3: Niitaka $\left(S^{1} S^{9}\right)$, lane 4: Okusankichi $\left(S^{5} S^{7}\right)$, lane 5: Imamuraaki $\left(S^{1} S^{6}\right)$, lane 6: Kinchaku $\left(S^{4} S^{\mathrm{k}}\right)$, lane 7: Sujeongbae, lane 8: Hannareum, lane 9: Shincheon, lane 10: Sooyoung, lane 11: Josaengwhangkum, and M: 100 bp DNA Ladder.

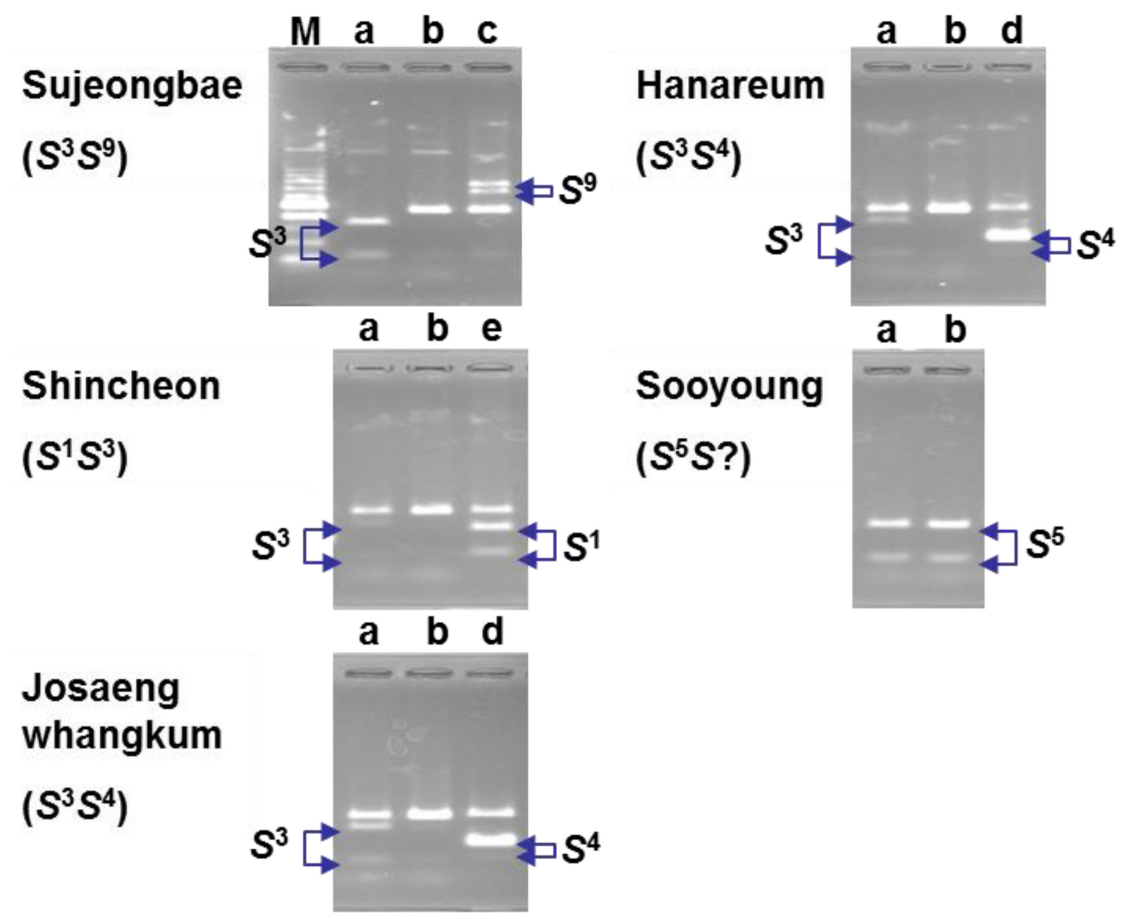

Fig. 2. $S$-genotypes analysis of five Korean bred pear cultivars by polymerase chain reaction (PCR)-restriction fragment length polymorphism analysis. The $S$-RNase PCR f[ragments were digested with $S$-allele-specific restriction enzymes; a: PpuMI $\left(S^{3}\right.$ and $\left.S^{5}\right)$, b: $A l w$ NI $\left(S^{5}\right)$, c: BstBI $\left(S^{9}\right)$, d: $N d e \mathrm{I}\left(S^{4}\right)$, e: $S f c \mathrm{I}\left(S^{1}\right)$. The digested fragments are indicated by arrows.

digested S-RNase fragments with PpuMI and AlwNI of 'Sooyoung' were identical and that was only $S^{5}$-RNase (Fig. 2). Thus, the only one $S$-RNase PCR product of 'Sooyoung' was identified; the other $S$-RNase PCR product was not amplified. Therefore the $S$-genotype of 'Sooyoung' was $S^{5}\left(S^{5} S\right.$ ?). The predicted $S$-genotype of 'Sooyoung' matched neither with registrant parent
'Niitaka' $\left(S^{3} S^{9}\right)$ nor with 'Soowhangbae' $\left(S^{3} S^{4}\right)$.

\section{DISCUSSION}

In this study, we confirmed the parents of nine Korean pear cultivars by using the 53 SSR markers and $S$-RNase 
based PCR-RFLP analysis. The SSR and $S$-genotypes of 'Chuwhangbae', 'Whangkeumbae' and 'Sujeongbae' matched with registrant parents; 'Imamuraaki' $\times$ 'Nijisseiiki', 'Nijisseiki' ‘'Niitaka' and mutant of 'Niitaka', respectively (Table 4). However, the SSR genotypes of 'Hannareum' $\left(S^{3} S^{4}\right)$ and 'Josaengwhangkum' $\left(S^{3} S^{4}\right)$ did not matched with the SSR genotypes of registrant parents, but those matched with SSR genotypes of the new candidate parents ('Niitaka' $\left(S^{3} S^{9}\right) \times$ 'Tama' $\left(S^{4} S^{5}\right)$ for 'Hannareum' and 'Niitaka' $\left(S^{3} S^{9}\right) \times$ 'Nijisseiki' $\left(S^{2} S^{4}\right)$ for 'Josaengwhangkum'. Thus our results confirmed that at least one parent of those two pear cultivars was wrongly reported earlier (Table 4).

The $S$-genotypes of 'Soowhangbae' and 'Sunhwang' were determined as $S^{3} S^{4}$ and $S^{3} S^{5}$ respectively by Kim et al. (2002). However, the authors were unable to confirm the parentage of these two Korean pear cultivars at that time. In this study, the SSR genotypes of two pear cultivars and their registrant parents were found different. Our results suggested that 'Nijiiseiki' ×'Niitaka' and 'Niitaka' ×'Shinsui' were the candidate parents of 'Soowhangbae' and 'Sunhwang' respectively (Table 4). The $S^{3} S^{4}$ genotype of 'Soowhangbae' could not be obtained from registrant parent 'Chojuro' $\left(S^{2} S^{3}\right) \times$ 'Kimitsukawase' $\left(S^{1} S^{5}\right)$, but that could be obtained from the new candidate parents 'Nijisseiki' $\left(S^{2} S^{4}\right) \times$ 'Niitaka' $\left(S^{3} S^{9}\right)$ (Table 4). 'Shincheon' and 'Sooyoung' were also different from their registrant parents by their SSR genotyping and $S$-genotyping. 'Shincheon' $\left(S^{1} S^{3}\right)$ might be originated from the following candidate parent combination: 'Niitaka' $\left(S^{3} S^{9}\right) \times$ 'Chouju'
$\left(S^{1} S^{5}\right)$ but the candidate parent of 'Sooyoung' was not possible to determine by comparing SSR genotypes of 96 Japanese pear cultivars. Therefore, it could be suggested that 'Sooyoung' was possibly a bred of a Korean local cultivars and was not probably a bred of any Japanese pear cultivars (Table 4).

The three Korean pear cultivars namely, 'Whangkeumbae', 'Soowhangbae' and 'Josaengwhangkum' were bred by crossing between 'Niitaka' $\times$ 'Nijiiseiki' as these three cultivars had identical $\left(S^{3} S^{4}\right) S$-genotypes even though fruit characters of those three were different (http://www. nihhs.go.kr/search/search.asp). Seven out of nine Korean bred pear cultivars namely 'Whangkeumbae', 'Hanareum', 'Shincheon', 'Soowhangbae', 'Josengwhangkeum' and 'Sunhwang' were bred using 'Niitaka' as a parent probably because 'Niitaka' had very high yield potential, producing large fruit with an attractive appearance and good storability (Saito 2016).

In conclusion, we have used 53 reliable SSR markers this study, which were found substantial to determine pear parentage, and the use of $S$-RNase genes associated PCR-RFLP systems led us towards a reliable determination of $S$-genotypes. This methods and approaches have been used in this study could be successfully utilized in identifying cultivars with highly diverse $S$-genotypes and also in identifying obscure relationships between parents and progenies of pear and apple.

Table 4. S-genotypes relationship among the 9 Korean pear cultivars and their parents.

\begin{tabular}{|c|c|c|c|c|}
\hline Cultivars & Registrant parents & SSR genotyping ${ }^{z)}$ & Candidate parents & $S$-genotype \\
\hline Sujeongbae & Mutant of Niitaka $\left(S^{3} S^{9}\right)$ & $\mathrm{O}$ & & $S^{3} S^{9}$ \\
\hline Chuwhangbae $e^{\mathrm{y})}$ & Imamuaraki $\left(S^{1} S^{6}\right) \times$ Nijisseiki $\left(S^{2} S^{4}\right)$ & $\mathrm{O}$ & & $S^{4} S^{6}$ \\
\hline Whangkeumbae ${ }^{\mathrm{y})}$ & Niitaka $\left(S^{3} S^{9}\right) \times$ Nijisseiki $\left(S^{2} S^{4}\right)$ & $\mathrm{O}$ & & $S^{3} S^{4}$ \\
\hline Hanareum & Niitaka $\left(S^{3} S^{9}\right) \times$ Chuwhangbae $\left(S^{4} S^{6}\right)$ & $\mathrm{X}$ & Niitaka $\left(S^{3} S^{9}\right) \times$ Tama $\left(S^{4} S^{5}\right)$ & $S^{3} S^{4}$ \\
\hline Shincheon & Niitaka $\left(S^{3} S^{9}\right) \times$ Chuwhangbae $\left(S^{4} S^{6}\right)$ & $\mathrm{X}$ & Niitaka $\left(S^{3} S^{9}\right) \times$ Chouju $\left(S^{1} S^{5}\right)$ & $S^{1} S^{3}$ \\
\hline Soowhangbae ${ }^{\mathrm{y})}$ & Chojuro $\left(S^{2} S^{3}\right) \times$ Kimitsukawase $\left(S^{1} S^{5}\right)$ & $\mathrm{X}$ & Niitaka $\left(S^{3} S^{9}\right) \times$ Nijisseiki $\left(S^{2} S^{4}\right)$ & $S^{3} S^{4}$ \\
\hline Josaengwhangkum & Niitaka $\left(S^{3} S^{9}\right) \times$ Shinko $\left(S^{4} S^{9}\right)$ & $\mathrm{X}$ & Niitaka $\left(S^{3} S^{9}\right) \times$ Nijisseiki $\left(S^{2} S^{4}\right)$ & $S^{3} S^{4}$ \\
\hline Sunhwang ${ }^{\mathrm{y})}$ & Niitaka $\left(S^{3} S^{9}\right) \times$ Okusankichi $\left(S^{5} S^{7}\right)$ & $\mathrm{X}$ & Niitaka $\left(S^{3} S^{9}\right) \times$ Shinsui $\left(S^{4} S^{5}\right)$ & $S^{3} S^{5}$ \\
\hline Sooyoung & Niitaka $\left(S^{3} S^{9}\right) \times$ Soowhangbae $\left(S^{3} S^{4}\right)$ & $\mathrm{X}$ & $? \times$ Okusankichi $\left(S^{5} S^{7}\right)$ & $S^{5} S ?$ \\
\hline
\end{tabular}

${ }^{\mathrm{z})} \mathrm{O}$ is matched the simple sequence repeat (SSR) genotypes among the registrant parents and cultivar, $\mathrm{X}$ is not matched the SSR genotypes among the registrant parents and cultivar.

${ }^{\text {y) }}$-genotypes were previously determined by Kim et al. (2002). 


\section{ACKNOWLEDGEMENTS}

We thank Yoon-Kyeong Kim in Pear Research Station, National Institute of Horticultural \& Herbal Science for plant materials of Korean bred pear cultivars. This research was supported by Golden Seed Project (Center for Horticultural Seed Development, No. 213003-04-4-SB110) Ministry of Agriculture, Food and Rural Affairs (MAFRA), Ministry of Oceans and Fisheries (MOF), RDA and Korea Forest Service (KFS).

\section{REFERENCES}

Castillo C, Takasaki T, Saito T, Yoshimura Y, Norioka S, Nakanishi T. 2001. Reconsideration of $S$-genotype assignments and discovery of a new allele based on $S$-RNase PCRR-FLP in Japanese pear cultivars. Breed. Sci. 51: 5-11.

Cho KH, Shin IS, Kim SH, Kim JH, Kim DH, Shin YU, et al. 2012. Identification of Korean pear cultivars using combinations of SCAR markers. Hort. Environ. Biotechnol. 53: 228-236.

Fernandez-Fernandez F, Harvey NG, James CM. 2006. Isolation and characterization of polymorphic microsatellite markers from European pear (Pyrus communis L.). Mol. Ecol. Notes 6: 1039-1041.

Fujii H, Ogata T, Shimada T, Endo T, Shimizu T, Omura M. 2007. Development of a novel algorithm and the computer program for the identification of minimal marker sets of discriminating DNA markers for efficient cultivar identification. Proc. of the Plant \& Animal Genomes XV Conference. International Plant \& Animal Genome, San Diego, CA. p.883.

Hiratsuka S, Kubo T, Okada Y. 1998. Estimation of selfincompatibility genotype in Japanese pear cultivars by stylar protein analysis. J. Jpn. Soc. Hort. Sci. 67: 491-496.

Hwang HS, Kim WC, Shin IS, Cho HM, Shin YU, Lee DK, et al. 2005a. Breeding of a new yellow green pear cultivar 'Josengwhangkeum' (Pyrus pyrifolia Nakai) with high quality for summer season. Korean J. Hort. Sci. Technol. 23: 56-59.

Hwang HS, Shin IS, Kim WC, Cho HM, Shin YU, Hwang JH. 2002. Breeding of the new early season pear cultivar
Shincheon. Acta Hort. 587: 299-320.

Hwang HS, Shin IS, Kim WC, Shin YU, Hwang JH, Hong SS. 2005b. Breeding of pear (Pyrus pyrifolia Nakai) cv. Hanareum characterized by early maturity and superior fruit quality. Korean J. Hort. Sci. Technol. 23: 60-63.

Ishimizu T, Inoue K, Shimonaka M, Saito T, Terai O, Norioka S. 1999. PCR-based method for identifying the $S$-genotypes of Japanese pear cultivars. Theor. Appl. Genet. 98: 961-967.

Ishimizu T, Norioka S, Nakanishi T, Sakiyama F. 1998. $S$-genotype of Japanese pear 'Hosui'. J. Jpn. Soc. Hort. Sci. 67: 35-38.

Kim H, Kakui H, Koba T, Hirata Y, Sassa H. 2007. Cloning of a new S-RNase and development of a PCR-RFLP system for the determination of the S-genotypes of Japanese pear. Breed. Sci. 57: 159-164.

Kim H, Nou I. 2016. Confirmation of parentage of the pear cultivar 'Niitaka' (Pyrus pyrifolia) based on selfincompatibility haplotypes and genotyping with SSR markers. Korean J. Hort. Sci. Technol. (in press).

Kim H, Terakami S, Nishitani C, Kurita K, Kanamori H, Katayose Y, et al. 2012. Development of cultivar-specific DNA markers based on retrotransposon-based insertional polymorphism in Japanese pear. Breed. Sci. 62: 53-62.

Kim HT, Hirata Y, Nou IS. 2002. Determination of S-genotypes of pear (Pyrus pyrifolia) cultivars by S-RNase sequencing and PCR-RFLP analyses. Mol. Cells 13: 444-451.

Kim YS, Hong KH, Kim JB, Yiem MS, Lee UJ, Kim WC, et al. 1986. A new late-season pear cultivar, 'Chuwhangbae'. Res. Rpt. RDA (Hort.). 28: 57-61.

Kimura T, Sawamura Y, Kotobuki K, Matsuta N, Hayashi T, Ban Y, et al. 2003. Parentage analysis in pear cultivars characterized by SSR marker. J. Jpn. Soc. Hort. Sci. 72: 182-189.

Kitahara K, Matsumoto S, Yamamoto T, Soejima J, Kimura T, Komatsu H, et al. 2005. Parent identification of eight apple cultivars by S-RNase analysis and simple sequence repeat markers. HortScience 40: 314-317.

Machida Y, Sato Y, Kozaki I, Seiki K. 1982. S-genotypes of several cultivars of Japanese pear and the question of the parents of 'Hosui' (in Japanse). J. Jpn. Soc. Hort. Sci. 51(Suppl. 2): 58-59.

Monte-Corvo L, Goulão L, Oliveira C. 2001. ISSR analysis of cultivars of pear and suitability of molecular markers for 
clone discrimination. J. Am. Soc. Hort. Sci. 126: 517-522.

Moriya S, Iwanami H, Okada K, Yamamoto T, Abe K. 2011. A practical method for apple cultivar identification and parent-offspring analysis using simple sequence repeat markers. Euphytica 177: 135-150.

Nishitani C, Terakami S, Sawamura Y, Takada N, Yamamoto T. 2009. Development of novel EST-SSR markers derived from Japanese pear (Pyrus pyrifolia). Breed. Sci. 59: 391-400.

Oh Y, Kim YK, Kim D. 2015. Current status of knowledge and research perspectives in Korean pear genomics. Plant Breed. Biotech. 3: 323-332.

Saito T. 2016. Advances in Japanese pear breeding in Japan. Breed. Sci. 66: 46-59.

Sawamura Y, Saito T, Takada N, Yamamoto T, Kimura T, Hayashi T, et al. 2004. Identification of parentage of Japanese pear 'Housui'. J. Jpn. Soc. Hort. Sci. 73: 511-518.

Sawamura Y, Takada N, Yamamoto T, Saito T, Kimura T, Kotobuki K. 2008. Identification of parent-offspring relationships in 55 Japanese pear cultivars using S-RNase allele and SSR markers. J. Jpn. Soc. Hort. Sci. 77: 364-373.

Shin IS, Hwang HS, Shin YU, Kim WC. 2007. ‘Sooyoung': a mid-season pear (Pyrus pyrifolia Nakai) cultivar with high soluble solids and medium size. J. Am. Pomol. Soc. 61: 170-173.

Shin IS, Kim WC, Hwang HS, Shin YU. 2002. Achievements of pear breeding in Korea. Acta Hort. 596: 247-250.

Shoda M, Urasaki N, Sakiyama S, Terakami S, Hosaka F, Shigeta N, et al. 2012. DNA profiling of pineapple cultivars in Japan discriminated by SSR markers. Breed. Sci. 62: 352-359.

Takasaki T, Okada K, Castillo C, Moriya Y, Saito T, Sawamura Y, et al. 2004. Sequence of the $\mathrm{S}_{9}-\mathrm{RNa}$ e cDNA and PCR-RFLP system for discriminating $\mathrm{S}_{1}$ - to $\mathrm{S}_{9}$-allele in Japanese pear. Euphytica 135: 157-167.

Teng Y, Tanabe K, Tamura F, Itai A. 2002. Genetic relationships of Pyrus species and cultivars native to East Asia revealed by randomly amplified polymorphic DNA markers. J. Am. Soc. Hort. Sci. 127: 262-270.

Yamamoto T, Kimura T, Hayashi T, Ban Y. 2006. DNA profiling of fresh and processed fruits in pear. Breed. Sci. 56: $165-171$.

Yamamoto T, Kimura T, Shoda M, Ban Y, Hayashi T, Matsuta N. 2002. Development of microsatellite markers in Japanese pear (Pyrus pyrifolia Nakai). Mol. Ecol. Notes 2: 14-16.

Yamamoto T, Kimura T, Soejima J, Sanada T, Ban Y, Hayashi T. 2004. Identification of quince varieties using SSR markers developed from pear and apple. Breed. Sci. 54: 239-244.

Yamamoto T, Kimura T, Terakami S, Nishitani C, Sawamura $\mathrm{Y}$, Saito $\mathrm{T}$, et al. 2007. Integrated reference genetic linkage maps of pear based on SSR and AFLP markers. Breed. Sci. 57: 321-329. 